vin and the New England "Ice Saints" (May 10) seems to be a similar fiction, according to the late Waldo E. Forbes. Where such irregularities appear in the mean of a number of years, they appear to be the result of one or more extreme occurrences.

The well-merited praise that Professor Ward bestows upon the new temperature charts of the Atlas of American Agriculture could equally well be turned by others upon his own splendid discussion of them.

\section{LeRoy Meisinger}

Washington, D. C.

\section{SPECIAL ARTICLES}

\section{THE PRODUCTION OF NON-DISJUNCTION BY X-RAYS}

Is a previous issue of this journal ${ }^{1}$ the writer described certain experiments which showed that the X-chromosome could be "eliminated" from the egg of Drosophila by X-rays. In these experiments red-eyed, homozygous, virgin females were $\mathrm{X}$-rayed and crossed with white-eyed males. A total of twenty-four exceptional sons (white-eyed) were produced by the $X$-rayed females; fourteen out of the nineteen fertile X-rayed females producing exceptions. All excepting one of the twenty-four exceptional sons obtained from the X-rayed females were from eggs laid within six days of the time of X-raying and they could be divided into two groups corresponding to eggs laid during the earlier and later part of this period. Plough $^{2}$ has shown that maturation of the eggs in Drosophila melanogaster occupies approximately six days. . It therefore seems probable that the $\mathrm{X}$-rays act on the eggs while in one of the maturation divisions.

In the experiments referred to above only exceptional sons were recorded. In primary non-disjunction as investigated by Bridges $^{3}$ both exceptional sons and exceptional daughters occur. When, however, the female parent is homozygous for the dominant allelomorph as in the case of the X-ray experiments, the ex-

\footnotetext{
1 Scrence, N. S., Vol. LIV, September 23, 1921.

2 Jour. Exp. Zool., Vol. 24, No. 2, 1917.

3 Genetics, Vol. 1, p. 1-52, 107-163, 1916.
}

ceptional daughters are indistinguishable externally from their regular sisters.

The experiments to be described were planned to determine whether exceptional daughters were produced as a result of X-rays. Accordingly homozygous white-eyed females were crossed to eosin-eyed miniature-winged males. The regular offspring of such a cross are eosineyed, normal-winged daughters and white-eyed normal-winged sons. The exceptions are whiteeyed, normal-winged daughters and eosin-eyed, miniature-winged sons. In the experiments, white-eyed, virgin females from stock obtained from Dr. T. H. Morgan and used in the previous $\mathrm{X}$-ray experiments, were mated to eosineyed, miniature-winged males from stock obtained from H. H. Plough. The females used both for the controls and for X-raying, were all sisters, being from the first generation of a single pair of white-eyed flies. The virginity of these was secured by isolating pupæ in test tubes. The X-raying ${ }^{4}$ was done soon after the flies emerged from the pupa cases and they were immediately mated. The males used in the matings were, in the greater number of the experiments, the offspring of a single pair of eosin-eyed, miniature-winged flies. (This was probably an unnecessary precaution). Seventeen of the control pairs were fertile and one pair or 6 per cent. produced one exceptional son (eosin-eyed and miniature-winged). The total number of offspring produced by the control pairs in the first generation was $1,743 \mathrm{fe}$ males and 1,726 males and the exceptional fly formed .06 per cent. of the males. Thirteen of the $\mathrm{X}$-rayed females were fertile. Nine of them or 69 per cent. produced exceptions, two daughters' (white-eyed and normal-winged like their mothers) and twelve sons (eosin-eyed and miniature-winged ${ }^{5}$ like their fathers). The

4 The X-ray dosage and the technique of these experiments cannot be adequately described in a short note such as the present. They will be described in detail in a more extended paper to appear shortly.

5 In the case of three of the exceptional sons the wing character was not determined. Two of them were obtained by dissecting late pupal stages and one died before its wings had expanded. 
two female exceptions were the daughters of different $\mathrm{X}$-rayed females. The total number of daughters produced by the $\mathrm{X}$-rayed females was 512 and the two exceptions formed .39 per cent. of them. The total number of sons produced by the same $\mathrm{X}$-rayed females was 467 and the twelve exceptions form 2.5 per cent. of them. It should further be noted that four of the thirteen fertile X-rayed females produced less than ten offspring and that each, $i$. e., 100 per cent of the nine X-rayed females which produced more than ten offspring produced one or more exceptional daughters or sons.

The exceptional son of the control female was mated and found to be sterile. Eight of the twelve exceptional sons of the X-rayed females were mated and proved sterile. The other four exceptional sons of the X-rayed females were either dead when found or died soon afterwards. Bridges ${ }^{3}$ and Safir $^{6}$ both found that exceptional males arising from primary non-disjunction were sterile. One of the exceptional daughters was fertile, the other sterile.

It is, of course, not certain that both of the exceptional daughters obtained from the $\mathrm{X}$ rayed females were produced as a result of the $\mathrm{X}$-rays. Safir ${ }^{6}$, working on primary non-disjunction in white-eyed stock, found two exceptional females and thirteen exceptional males in a total of 21,773 offspring. A consideration of this and the fact that no exceptional daughters were produced by the control females and that the exceptional daughters came from different $\mathrm{X}$-rayed parents makes it seem extremely unlikely that both the exceptional daughters were the result of natural non-disjunction. It is interesting to note that the unequal ratio of exceptional males to exceptional females, six to one, found in the offspring of the X-rayed females, is approximately the same as that found for natural non-disjunction in whiteeyed females by Safir.

Bridges in his work on non-disjunction ${ }^{3}$ has clearly demonstrated that the exceptional males arising from primary non-disjunction come

6 Genetics, Vol. 5, No. 5, 1920. from eggs which are without an $\mathrm{X}$ chromosome and are fertilized by an $\mathrm{X}$ chromosome bearing sperm. Such males have the chromosome formula XO. The exceptional females caused by primary non-disjunction, he shows to be due to the fertilization of an egg having two Xchromosomes by a $\mathrm{Y}$ chromosome bearing sperm. Such females have the chromosome formula XXY. This evidence seems to justify the assumption that the exceptional flies produced as a result of the action of $\mathrm{X}$-rays have the chromosome formulas found by Bridges to occur as the result of natural primary nondisjunction; and the conclusion that an effect of X-rays when applied to eggs during maturation is to cause non-disjunction. This makes it probable that the $\mathrm{X}$-rays have a direct effect on the germ cell, causing an increase in the tendency, already seen in the occurrence of natural non-disjunction, for the two $\mathrm{X}$ chromosomes to fail to separate in the maturation of the egg. The question as to whether this effect is due to a modification of the physical properties of the $\mathrm{X}$ chromosomes or of the protoplasm surrounding them will not be discussed here.

When primary exceptional females are crossed to males like their fathers they produce further exceptions. As shown by Bridges ${ }^{3}$ secondary exceptional females oceur when the two $\mathrm{X}$ chromosomes are included in the mature egg and exceptional males when the two $\mathrm{X}$ chromosomes pass into a polar body and leave only the $\mathrm{Y}$ chromosome in the mature egg. When the egg containing two $\mathrm{X}$ chromosomes is fertilized by a sperm containing a $\mathrm{Y}$ chromosome the resulting female lives and is like its exceptional mother. When the egg containing only the $\mathrm{Y}$ chromosome is fertilized by a sperm containing an $\mathrm{X}$ chromosome the resulting male lives and is like its father. The two exceptional daughters of the X-rayed females were mated to eosin-eyed miniature-winged males. The daughter which proved to be sterile was found on dissection to have only one undeveloped ovary. The other which was fertile produced 174 regular daughters, 198 regular sons, 1 exceptional daughter, and 5 exceptional sons. The 
exceptional daughter (the $\mathrm{F}_{2}$ from the $\mathrm{X}$-rayed female) was fertile in a second mating with an eosin-eyed miniature-winged male (the first mating was sterile) and produced one exceptional daughter (white-eyed and normalwinged). Of the five exceptional males $\left(\mathrm{F}_{2}\right.$ from the $\mathrm{X}$-rayed female) two were proved to be fertile. The exceptional female $\left(\mathrm{F}_{3}\right.$ from the X-rayed female) proved fertile when mated with an eosin-eyed miniature-winged male and produced one exceptional daughter $\left(\mathrm{F}_{4}\right.$ of the X-rayed female). Since only one of the two exceptional females was fertile more data is required before it can be assumed that the exceptional females formed as a result of X-rays applied to the egg are fertile and produce further exceptions.

The experiments described confirm my earlier findings that $\mathrm{X}$-rays may be made to affect the germ cells and show further that the effect produced on the first generation, so far as at present investigated, is identical with primary nondisjunction.

The writer wishes to express his indebtedness to the Research Laboratory of the General Electric Company for their continued interest in this work, to Dr. T. H. Morgan and Dr. C. B. Bridges for helpful criticism and suggestions and to Mr. O. J. Irish for technical assistance.

UNion College,

Schenectady, N. Y.

\section{THE AMERICAN ASSOCIATION FOR THE ADVANCEMENT OF SCIENCE}

\section{REPORT OF THE SECRETARY-TREASURER OF THE PACIFIC DIVISION FOR THE CALENDAR YEAR ENDING DECEMBER 31, 1921}

January 1, 1921-Cash balance Receipts:

Received from the permanent secretary's office....................... $\$ 1,639.00$

Affiliated societies........................ 125.00

Dues and fees ................................ 520.00

Finance committee, Berkeley meeting
98.21

847.30

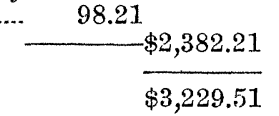

Expenditures:

Dues remitted to permanent secretary's office....................\$ 293.00

Supplies ................................... $\quad 6.58$

Salary 1921.................................... 825.00

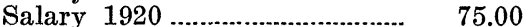

Office assistance........................... $\quad 300.00$

Postage and express................... $\quad 41.00$

Telephone and telegraph........... $\quad 20.45$

Expense general ......................... 5.00

Membership campaign................. 81.60

Finance committee, Berkeley meeting ................................. 5.34

Ukiah Observatory donation.... $\quad 50.00$

$\$ 1,702.97$

January 1, 1922-Cash balance................\$1,526.54

Balance Sheet, December 31, 1921

Assets

Equipment …..........................................\$ 235.73

Cash on hand............................................ 1,526.54

$\$ 1,762.27$

Liabilities

Permanent secretary's office........................\$1,426.54

Investment …................................................ 235.73

Sundry creditors............................................... 100.00

$\$ 1,762.27$

SUMmary OF ANNUAL DisbURSEMENTS FOR THE YEAR 1921

Supplies

6.58

Salary 900.00

Office assistance.................................... $\quad 300.00$

Postage and express.......................... $\quad 41.00$

Telephone and telegraph................. 20.45

Expense general

Membership campaign..................... $\quad 81.60$

Ukiah Observatory donation......... 50.00

These disbursemeents have been made from funds derived as follows:

Finance committee, Berkeley

meeting .......................... \$

Affiliated societies (assess-

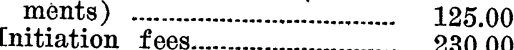

Receipts from the permanent

secretary's office....................... 956.76

92.87

230.00

$\$ 1,404.63$

Comparative Statement of Receipts and DisBURSEMENTS FOR THE YEARS 1920 AND 1921

1920

1921

Received from the permanent secretary's office :

Balance on account 1919......\$ 750.00

Account 1920 and 1921........ 1,014.00

Account 1921-1922

$\$ 1,639.00$

Received from affiliated societies

Received from new members, dues

Received from new members, initiation fees.

115.00

125.00

109.00

290.00

163.00

230.00 